\title{
CHARACTERIZATION AND STOICHIOMETRY OF THE CYANIDATION REACTION IN NaOH OF ARGENTIAN WASTE TAILINGS OF PACHUCA, HIDALGO, MÉXICO
}

\author{
${ }^{1 *}$ Francisco PATIÑO CARDONA, ${ }^{2}$ Antonio ROCAVALLMAJOR, ${ }^{3}$ Mizraím Uriel FLORES GUERRERO, \\ ${ }^{4}$ Martín. REYES PÉREZ, ${ }^{4}$ Julio César JUÁREZ TAPIA, ${ }^{5,6}$ Iván Alejandro REYES DOMÍNGUEZ, \\ 'Osvaldo DELGADO VASALLO
}

1'Ingeniería en Energía - Universidad Politécnica Metropolitana de Hidalgo, Boulevar Acceso a Tolcayuca 1009, Ex - Hacienda San Javier, 43860, Tolcayuca, Hidalgo, México,franciscopatinocardona@gmail.com

${ }^{2}$ Departament de Ciència de Materials i Química, Física - Facultat de Química - Universitat de Barcelona, Martí i Franquès 1, 08028 Barcelona, Spain,roca@ub.edu

${ }^{3}$ Área Electromecánica Industrial - Universidad Tecnológica de Tulancingo, Camino a Ahuehuetitla, 501, Col. Las Presas, Tulancingo, Hidalgo, 43645, México,mflores@utec-tgo.edu.mx

${ }^{4}$ Área Académica de Ciencias de la Tierra y Materiales - Universidad Autónoma del Estado de Hidalgo, Carretera Pachuca-Tulancingo Km. 4.5, C.P. 42184, Mineral de la Reforma, Hidalgo, México, mreyes@uaeh.edu.mx, jcjuarez@uaeh.edu.mx

${ }^{5}$ CONACyT-Consejo Nacional de Ciencia y Tecnología, Colonia Crédito Constructor Del. Benito Juárez, 03940, México, D.F., México, ivanalejandro2001@hotmail.com

${ }^{6}$ Instituto de Metalurgia - Universidad Autónoma de San Luis Potosí, Avenida Sierra Leona No. 550, Lomas 2 da. Sección, 78210, San Luis Potosí, S.L.P., México, ivanalejandro2001@hotmail.com

https://doi.org/10.37904/metal.2020.3578

\begin{abstract}
A chemical, mineralogical and granulometric characterization of the waste tailings of Pachuca, Hidalgo, Mexico, was conducted. Characterization results indicate that these argentian wastes contain $56 \mathrm{~g} \mathrm{Ag} \mathrm{ton}^{-1}$ in a quartz matrix, where silver is present as metal, as argentite and as argentian-jarosite. Results on the nature of the alkaline cyanidation reaction demonstrate that it can be divided into two processes: the first process consists of a quick cyanidation of the metal silver and of argentite. A second process then takes place: the alkaline decomposition of the argentian-jarosite where the decomposition products of this ore are quickly cyanided. Therefore, this second process consists of two consecutive phases, as previously observed in other studies on synthesized argentianjarosite-type compounds. The chemical-control and diffusive-control kinetic models were tested in order to determine which model controls the global alkaline cyanidation process. We found that once the quick cyanidation (process 1) of metal silver and argentite takes place, the experimental results corresponding to process 2 adapt to both models with a similar regression coefficient. It can be concluded that the global decomposition and cyanidation process of argentian-jarosite is controlled in a mixed manner. The experimental rate constant obtained in this study for the naturally formed jarosite was $0.007 \mathrm{~min}^{-1}$, which is very similar to that of the synthetic jarosite obtained in previous studies.
\end{abstract}

Keywords: Waste tailings, silver, cyanidation, kinetics

\section{INTRODUCTION}

The mining district comprising Pachuca and Real del Monte in the State of Hidalgo, México, has been providing the world with silver for 470 years. However, the argentian resources of this region have suffered an extensive 
exploitation, resulting in more than 100 million tons of waste tailings located in several sites around the city of Pachuca and surrounding municipalities. These tailings or mine dumps are becoming an environmental issue for the city of Pachuca and the Municipality of Mineral de la Reforma. There are mainly two causes for this: first, because, in periods of strong winds, dust clouds are formed which seriously affect the inhabitants' health; a second point is that these residues take up 1200 hectares, obstructing the city's proper and sustainable growth. Since the value of this precious metal is 16.666 US dollars perounce (as of December 10 2019 ) and these tailings contain $56 \mathrm{~g} \mathrm{Ag} \mathrm{ton}^{-1}$, it renders them economically appealing [1].

For these reasons, this piece of work presents an extensive reprocessing study of the Dos Carlos waste tailings of the city of Pachuca with the aim of: 1) Recovering the silver contained in those residues through different silver leaching methods. 2) Using these residues as alternative construction material and in the glass industry. This paper presents only the results of the granulometric, mineralogical and chemical characterization, as well as the stoichiometry of the cyanidation reaction in $\mathrm{NaOH}$ media of the Dos Carlos tailings located in the northeast area of the city of Pachuca. Of the mining metallurgical district of the company Real del Monte y Pachuca, these tailings are the second richest in silver. It is found in different forms: quartz matrix, distributed as metal silver, as argentite and as argentian-jarosite. This last ore is also called argentian potassium jarosite when it is synthesized in laboratories [2]. This compound is also obtained in the metallurgical industry, where the precipitation of jarosite has been widely used in the hydrometallurgical circuits of zinc as a means to control the impurities of the solutions containing it [3], generating millions of tons of this jarosite type compound that has a high silver content.

\section{EXPERIMENTAL}

\subsection{Materials}

A $2 \times 10^{3} \mathrm{~g}$ sample of the Dos Carlos waste tailings was obtained. It was wet- and dry- sieved with the Tyler standard series. It was thoroughly characterized by X-ray diffraction (XRD), Atomic Absorption Spectroscopy (AAS), Inductively Coupled Plasma (ICP), and Scanning Electron Microscopy with X-ray microanalysis (SEM-EDS). The silver content of the sample was $56 \mathrm{~g} \mathrm{Ag} \mathrm{ton}^{-1}$. The tailings' density was determined by means of a picnometer, using water as immersion medium. The result was $2.65 \mathrm{~g} \mathrm{~cm}^{-3}$.

\subsection{Experimental procedure}

It is known that, for obvious reasons, the cyanidation of ores is practiced at alkaline pH levels between 9 and 12 . The experiments were conducted in a conventional glass kettle coupled to a mechanical stirring system provided with an RPM meter, a thermometer and a pH meter to control the concentration of alkaline reagent. The kettle was also coupled to an electric heater that allows to dial temperature variations of $\pm 0.5^{\circ} \mathrm{C}$. The argentian tailings' cyanidation was conducted in a $500 \mathrm{~cm}^{3}$ kettle under the following experimental conditions: 40 gargentian tailings sample, $25^{\circ} \mathrm{C}, 1 \times 10^{-2} \mathrm{~mol} \mathrm{~L}^{-1}[\mathrm{NaOH}], 2.04 \times 10^{-2} \mathrm{~mol} \mathrm{~L}^{-1}\left[\mathrm{NaCN}\right.$ ], and a stirring rate of $750 \mathrm{~min}^{-1}$ in order to keep the solids suspended and to avoid the liquid film diffusion effect.

Since this study on the stoichiometry of alkaline cyanidation shows that silver ions are removed from the solids and diffuse towards thesolution, the reaction was followed by analysis of silverion sinthe liquid. In order to achieve this, samples of approximately $10 \mathrm{ml}$ were taken at previously selected time intervals. They were then filtered and analyzed by AAS. Alterations due to sampling and reagent addition were corrected through mass balance. The $x$ fraction of cyanided silver was calculated with the following:

$x=[\mathrm{Ag}]_{t} /[\mathrm{Ag}]_{\infty}$ 
where $[\mathrm{Ag}] \mathrm{t}$ is the concentration of silver at a time $t$, and $[\mathrm{Ag}]^{\infty}$ is the concentration of $\mathrm{Ag}$ after the solids have been completely leached.

The kinetic models $[4,5,6]$ selected for the experimental data on the cyanidation in $\mathrm{NaOH}$, were the following:

$$
\begin{array}{ll}
1-(1-x)^{1 / 3}=k_{\text {exp }} & \text { (chemical-control model) } \\
1-3(1-x)^{2 / 3}+2(1-x)=k_{\text {exp }} t & \text { (diffusive-control model) }
\end{array}
$$

Where $k_{\exp }$ is the experimental rate constant, $x=$ reacted fraction, and $t$ is the reaction time.

\section{RESULTS AND DISCUSSION}

Table 1 shows the particle size distribution and silver content for each of the particle sizes retained on the Tyler mesh series. It can be observed that the precious metal is mainly distributed between mesh sizes $200(74 \mu \mathrm{m})$ and $400(37 \mu \mathrm{m})$. The highest silver concentration $\left(147 \mathrm{~g} \mathrm{Ag} \mathrm{ton}^{-1}\right)$ was found at particle sizes under Tyler -400 ($37 \mu \mathrm{m})$.

Table 1 Particle size distribution and silver content (according to size distribution) of the waste tailings

\begin{tabular}{|c|c|c|c|c|c|}
\hline Mesh size & Mesh opening $(\mu \mathrm{m})$ & $\begin{array}{c}\text { Weight } \\
(\mathrm{g})\end{array}$ & $\begin{array}{c}\text { Retained } \\
(\%)\end{array}$ & $\begin{array}{c}\text { Ag content } \\
(\mathrm{g} / \mathrm{Ton})\end{array}$ & $\begin{array}{c}\text { Au content } \\
(\mathrm{g} / \text { Ton })\end{array}$ \\
\hline$-140+200$ & $-105+74$ & 15.58 & 15.58 & 59 & 0.60 \\
\hline$-200+270$ & $-74+53$ & 10.12 & 10.12 & 51 & 0.55 \\
\hline$-270+400$ & $-53+37$ & 4.50 & 4.50 & 60 & 0.65 \\
\hline-400 & -37 & 15.83 & 15.83 & 147 & 1.20 \\
\hline
\end{tabular}

Figure 1 presents the X-ray Diffraction (XRD) spectrum, showing the presence of jarosite $\left(\mathrm{KFe}_{3}\left(\mathrm{SO}_{4}\right)_{2}(\mathrm{OH})_{6}\right)$ in a quartz $\left(\mathrm{SiO}_{2}\right)$ matrix with other main species, such as orthoclase, albite $\left(\mathrm{NaAlSi}_{3} \mathrm{O}_{8}\right)$ andberlinite $\left(\mathrm{AlPO}_{4}\right)$. $\mathrm{Geyne}$ [7] reported this compound as argentian-jarosite; it is native to the Paricutin mine in the mining district of Pachuca and Real del Monte.

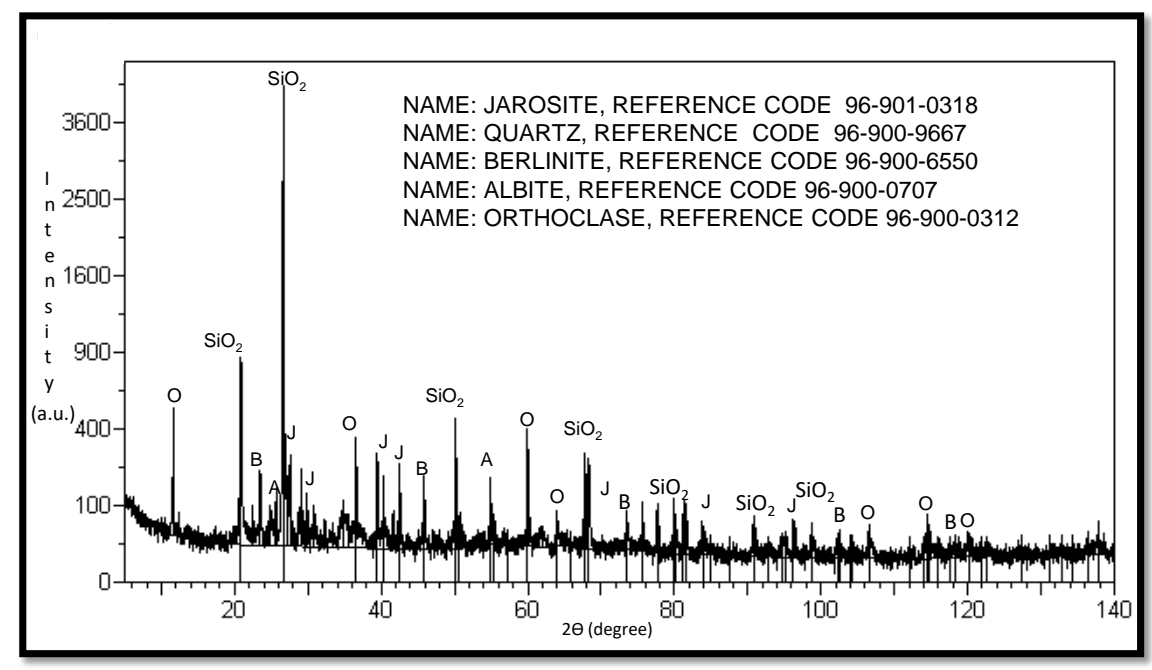

Figure $1 \mathrm{X}$-ray diffractogram of the tailings. The major species are: Quartz $\left(\mathrm{SiO}_{2}\right), \mathrm{O}-\mathrm{Orthoclase}\left(\mathrm{KAISiO}_{3}\right), \mathrm{A}$ Albite $\left(\mathrm{NaALSi}_{3} \mathrm{O}_{8}\right)$, B-Berlinite $\left(\mathrm{AlPO}_{4}\right)$ and J-Jarosite $\left(\mathrm{KFe}_{3}\left(\mathrm{SO}_{4}\right)_{2}(\mathrm{OH})_{6}\right)$ 
Table 2 summarizes the AAS and ICP chemical analysis data, where it can be observed that the silver and gold content is $56 \mathrm{~g} \mathrm{ton}^{-1}$ and $0.60 \mathrm{~g} \mathrm{ton}^{-1}$, respectively. It can also be noted that the major elements are silicon, sulfur and aluminum, whereas the minor elements are iron, potassium, strontium, calcium, sodium, phosphorus and barium. The rest are considered trace elements. Table 3 presents the tailings' quantitative chemical analysis by $\mathrm{X}$-ray Fluorescence (XRF, the chemical composition is given as oxides), which confirmed that the waste tailings are made of a quartz matrix whose $\mathrm{SiO}_{2}$ and $\mathrm{Ag}$ contents are $70.43 \% 55 \mathrm{~g} \mathrm{ton}^{-1}$, respectively. The problem is to explain how silver is distributed in the Dos Carlos waste tailings. In this respect SEM-EDS images show that the silver is distributed as follows: a) In metal form, as shown in Figure 2a, where an $8 \mu \mathrm{m}$ particle can be observed. Figure $\mathbf{2 b}$ shows the same particle's $X$-ray microanalysis (EDS), showing the typical intensity peaks of metal silver. b) In the form of argentite, as observed on Figure 3a, where argentite particles of up to $2 \mu \mathrm{m}$ were obtained; Figure $\mathbf{3 b}$ displays the EDS analysis of these particles, showing the typical intensity peaks of argentite. c) In the form of argentian-jarosite. Figure 4a shows argentian-jarosite particles finally scattered in the quartz matrix, and Figure $\mathbf{4 b}$ presents the EDS analysis of the argentian-jarosite particles, where the typical intensity peaks of this ore can be observed, with elements such as sulfur, iron, potassium and silver. This confirms that the peaks correspond to those of argentian-jarosite, also known as silver potassium jarosite when it is obtained in the laboratory [2].

Table 2 Chemical composition of the waste tailings Atomic Absorption Spectroscopy (AAS), and Inductively Coupled Plasma (ICP)

\begin{tabular}{|c|c|c|c|}
\hline Element & $\mathbf{W t} \%$ & Element & $\mathbf{W t} \%$ \\
\hline $\mathrm{Au}\left(\mathrm{g} \mathrm{ton}^{-1}\right)$ & $0.60 \mathrm{~g} \mathrm{ton}^{-1}$ & $\mathrm{Ca}$ & 0.200 \\
\hline $\mathrm{Ag}\left(\mathrm{g} \mathrm{ton}^{-1}\right)$ & $56 \mathrm{~g} \mathrm{ton}^{-1}$ & $\mathrm{Si}$ & 56.00 \\
\hline
\end{tabular}

Table 3 Quantitative chemical analysis of the waste tailings.

\begin{tabular}{|c|c|} 
X-ray Fluorescence (XRF) \\
\hline Element & $\mathbf{W t} \%$ \\
\hline $\mathrm{SiO}_{2}$ & 70.43 \\
\hline $\mathrm{Ag}$ & $55 \mathrm{~g} \mathrm{ton}^{-1}$ \\
\hline $\mathrm{Au}$ & $0.58 \mathrm{~g} \mathrm{ton}^{-1}$ \\
\hline
\end{tabular}
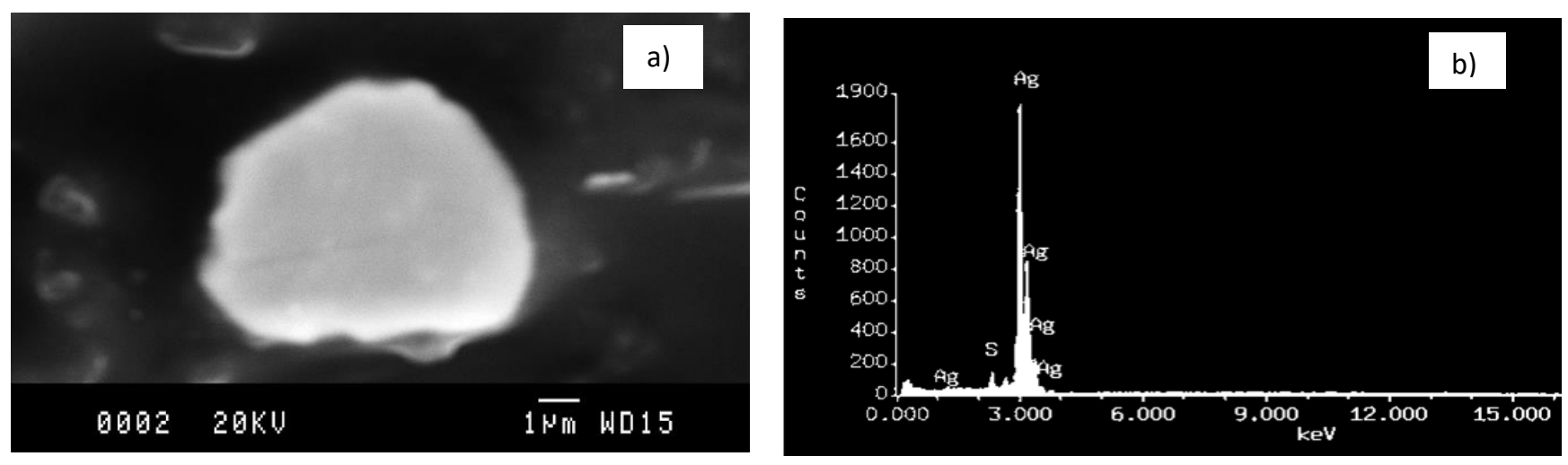

Figure 2a) SEM-backscattered electron image of a silver particle b) Energy dispersive X-ray microanalysis of Figure 2a 


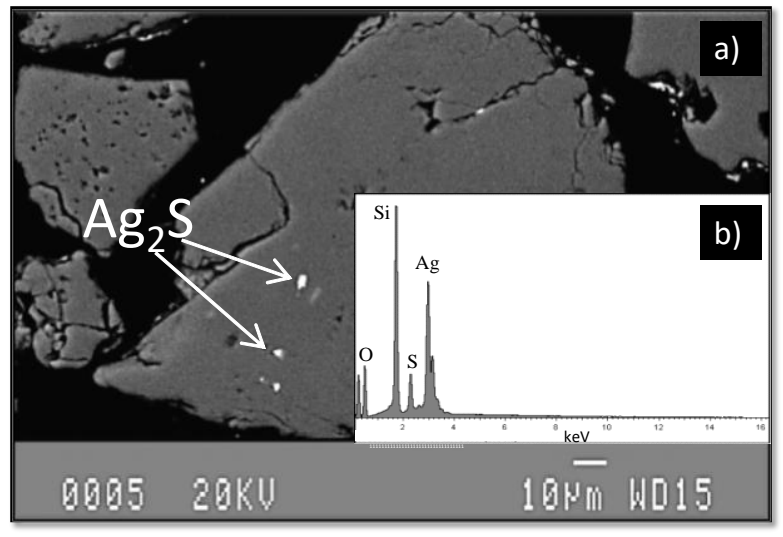

Figure 3a) SEM-backscattered electron image of argentite particles. b) Energy dispersive X-ray microanalysis of figure $\mathbf{3 a}$

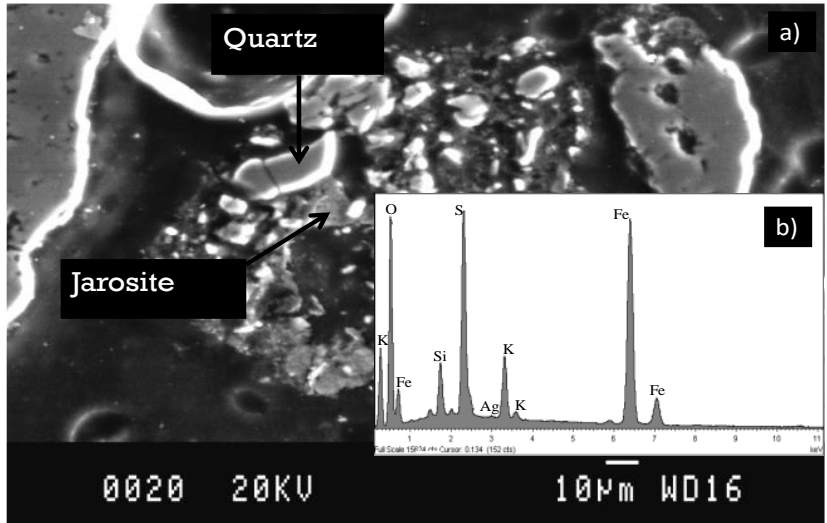

Figure 4 a) SEM-backscattered electron image of argentian potassium jarosite. b) Energy dispersive $\mathrm{X}$ ray microanalysis of figure $\mathbf{5 a}$

The results of the nature of the alkaline cyanidation reaction are shown in Figure 5, where it can be noticed that the first process consists of a quick cyanidation of the metal silver and silver corresponding to argentite. A second process then takes place: the alkaline decomposition of the argentian-jarosite. The decomposition products of this ore are quickly cyanided; therefore, this second process consists of two consecutive phases, as previously observed in other studies on synthesized argentian-jarosite-type compounds [8]. The reaction stoichiometry of the previously mentioned processes isdescribed as follows:

\section{Process 1:}

$2 \mathrm{Ag}_{(\mathrm{s})}+4 \mathrm{NaCN}_{(\mathrm{aq})}+1 / 2 \mathrm{O}_{2(\mathrm{~g})}+\mathrm{H}_{2} \mathrm{O}_{(\mathrm{l})} \stackrel{\mathrm{NaOH}}{\longrightarrow} 2 \mathrm{Na}\left[\mathrm{Ag}(\mathrm{CN})_{2}\right]_{(\mathrm{aq})}+2 \mathrm{NaOH}_{(\mathrm{aq})} \ldots$. quick

$\mathrm{Ag}_{2} \mathrm{~S}_{(\mathrm{s})}+4 \mathrm{NaCN}_{(\mathrm{aq})} \quad \underset{\mathrm{NaOH}}{\longrightarrow} 2 \mathrm{Na}\left[\mathrm{Ag}(\mathrm{CN})_{2}\right]_{(\mathrm{aq})}+\mathrm{Na}_{2} \mathrm{~S}_{(\mathrm{s})} \ldots$ quick

Process 2:

$\left(\mathrm{K}_{\mathrm{x}} \mathrm{Ag}_{1-\mathrm{x}}\right) \mathrm{Fe}_{3}\left(\mathrm{SO}_{4}\right)_{2}(\mathrm{OH})_{6(\mathrm{~s})}+[3+(1-\mathrm{x})] \mathrm{OH}^{-}{ }_{(\mathrm{aq})} \underset{\mathrm{xK}^{+}{ }_{(\mathrm{aq})}}{\stackrel{\mathrm{NaOH}}{\longrightarrow}}+(1-\mathrm{x}) \mathrm{Ag}(\mathrm{OH})_{(\mathrm{s})}+3 \mathrm{Fe}(\mathrm{OH})_{3}+2 \mathrm{SO}^{2-}{ }_{4(\mathrm{aq})} \ldots$. . slow

$(1-\mathrm{x}) \mathrm{Ag}(\mathrm{OH})_{(\mathrm{s})}+2 \mathrm{CN}^{-}{ }_{(\mathrm{aq})} \underset{\mathrm{NaOH}}{\longrightarrow}(1-\mathrm{x})\left[\mathrm{Ag}(\mathrm{CN})_{2}\right]^{2-}{ }_{(\mathrm{aq})}+(1-\mathrm{x}) \mathrm{OH}^{-}{ }_{(\mathrm{aq})} \ldots$. quick

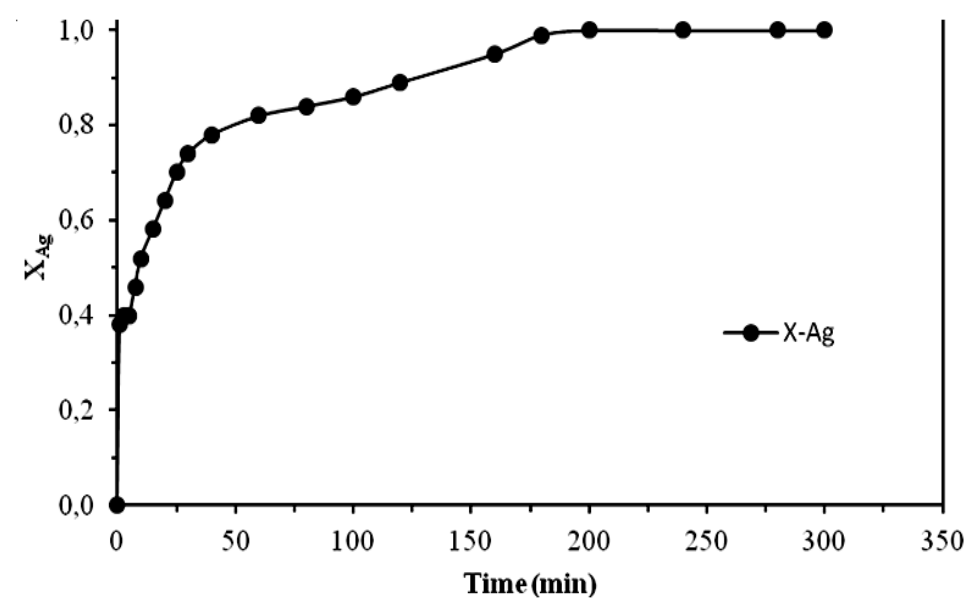

Figure 5 Cyanidation curve of silver: $2.04 \times 10^{-2} \mathrm{~mol} \mathrm{~L}^{-1}[\mathrm{NaCN}], 1 \times 10^{-2} \mathrm{~mol} \mathrm{~L}^{-1}[\mathrm{NaOH}]$ and $298 \mathrm{~K}$ 
The chemical-control and diffusive-control kinetic models were then tested in order to determine which controls of the global process of alkaline cyanidation. We found that once the quick cyanidation (process 1) of metal silver and argentite takes place, the experimental results corresponding to process 2 adapt to both models with a similar regression coefficient, as observed on Figure 6 . Therefore, it can be concluded that the global decomposition and cyanidation process of argentian-jarosite is controlled in a mixed manner. The experimental rate constant obtained in this study for the naturally formed jarosite was $0.007 \mathrm{~min}^{-1}$, which is very similar to that of the synthetic jarosite obtained in previous studies [9].

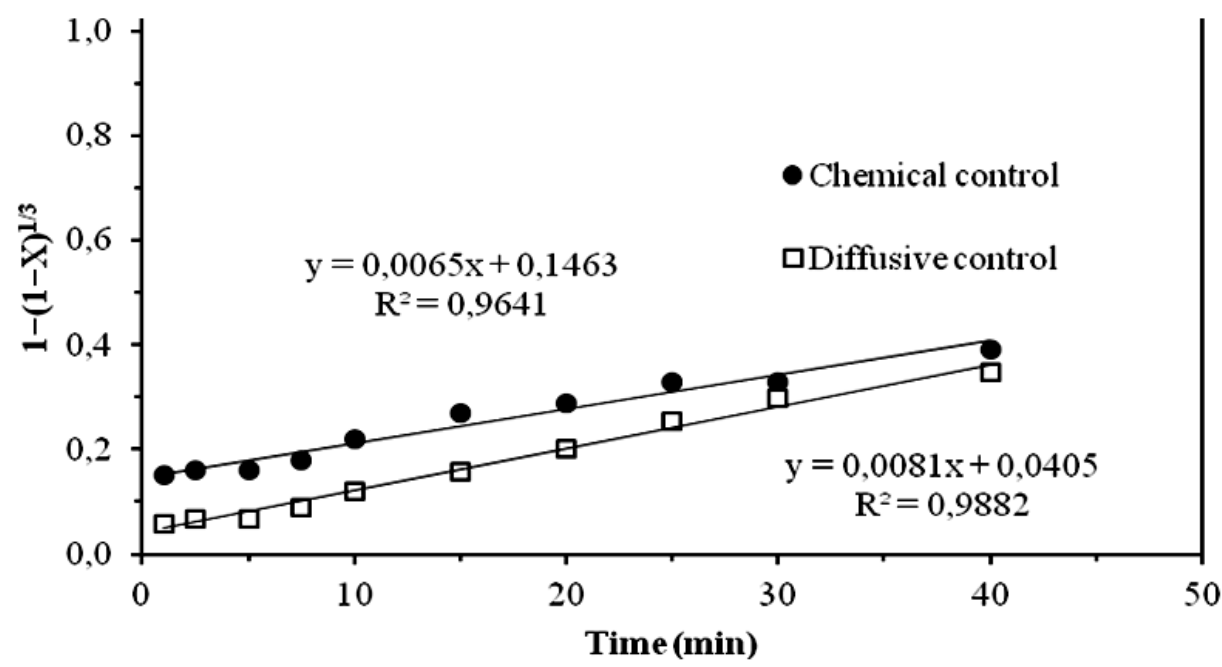

Figure 6 Representation of the chemical-control and diffusive-control models for the data in Table 3 and Figure 5

\section{CONCLUSIONS}

The Dos Carlos waste tailings located in Pachuca, Hidalgo, Mexico, are made of a quartz matrix that contains silver in metal form, as argentite and as argentian-jarosite. The silver content of these mining wastes is $56 \mathrm{~g} \mathrm{Ag}$ ton $^{-1}$. The stoichiometry of the alkaline cyanidation consists of: 1) Quick cyanidation of both metal silver and silver present in the form of argentite, and 2) Slow decomposition of the argentian-jarosite and quick cyanidation of the silver contained in the decomposition products. The experimental rate constant of the naturally formed argentianjarosite is similar to that of the synthesized silver potassium jarosite.

\section{ACKNOWLEDGEMENTS}

We would like to express our thans the Institute of Research in Earth Sciences and Materials of the UAEH, Mexico as well as to the Department of Materials Sciences, Chemistry and Physics of the University of Barcelona, Spain, for their technical support in this work.

\section{REFERENCES}

[1] BULLION RATES. Current silver prices. [online]. [viewed 2019-12-10]. Available from https://es.bullionrates.com/silver.htm

[2] DUTRIZAC, J.E., KAIMAN, S. Synthesis and properties of jarosite-type compounds. Canadiaan Mineralogist Mineral.1976, no. 14, pp. 151-158. 
[3] ARREGUI, B., GORDON, A. R. STEINTVELT, G. The jarosite process - Past, present and future. In: TMS-AIME, New York, 1979, pp. 97-123.

[4] LEVENSPIEL, O. Ingeniería de las reaccion esquímicas: Barcelona, Spain: Editorial Reverté, 2005, pp. 393-411.

[5] BALLESTER, A., VERDEJA, L.F., SANCHO, J. Metalurgia Extractiva. Madrid, Spain: Editorial Síntesis, 2001,vol. 1, pp.182-189.

[6] SOHN, H.Y., WADSWORTH, M.E. Cinética de losprocesos de metalurgia extractiva. Mexico: Editorial Trillas, 1986, pp. 167-194.

[7] GEYNE, A. R., FRIES, C., SEGERSTROM BLACK, R.F., WILSON, I.F. Geología y Yacimientos Minerales del Distrito Minero de Pachuca-Real del Monte, Estado de Hidalgo, México. Mexico: Consejo de Recursos Naturales no Renovables, Publicación 5-E, 1963, p. 96.

[8] ROCA, A., PATIÑO, F., VIÑALS, J., NÚÑEZ, C. Alkaline decomposition-cyanidation kinetics of argento-jarosite. Hydrometallurgy.1993, vol. 33, pp. 341-358.

[9] ROCA, A., CRUELLS, M., PATIÑO, F., RIVERA, I., PLATA, M. Kinetic model for the cyanidation of silver ammonium jarosite in $\mathrm{NaOH}$ medium. Hydrometallurgy. 2006, vol. 81, pp. 15-23. 